\title{
Perancangan Aplikasi Daring Bimbingan Tugas Akhir
}

\author{
Helen Sastypratiwi $^{\# 1}$, Aprillita Dwiyani ${ }^{\# 2}$

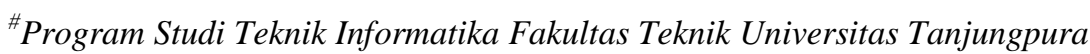 \\ ${ }^{1}$ helensastypratiwi@gmail.com \\ 2aprillita.09013@gmail.com
}

\begin{abstract}
Abstrak- Menurut kamus besar Bahasa Indonesia, bimbingan memilika arti sebagai petunjuk(penjelasan) cara mengerjakan sesuatu, tuntunan atau pimpinan. Dalam universitas terdapat tahap akhir yang harus ditempuh oleh mahasiswa yaitu tugas akhir yang dalam prosesnya dibimbing oleh satu atau dua orang dosen pembimbing.Penelitian ini mengusulkan perancangan aplikasi daring bimbingan tugas akhir yang diperuntukkan bagi mahasiswa dan dosen. Aplikasi ini dirancang dalam lingkup Program Studi Teknik Informatika Universitas Tanjungpura berdasarkan informasi dan prosedur pembuatan tugas akhir Program Studi Teknik Informatika. Adapun pengujian yang digunakan adalah metode black box dengan menggunakan teknik sample testing dan metode UAT (User Acceptance Test) untuk memeriksa apakah sistem dapat berjalan dengan benar sesuai dengan yang diharapkan oleh pengguna. Hasil dari penelitian ini memberikan kemudahan bagi kedua dosen pembimbing untuk berkomunikasi mengenai mahasiswa bimbingannya dalam forum pembimbing karena proses bimbingan dapat dilakukan secara daring serta dilengkapi dengan pemberitahuan secara realtime melalui pesan elektronik atau email.
\end{abstract}

Kata kunci - tugas akhir, daring, bimbingan

\section{Pendahuluan}

Bidang pendidikan khususnya Universitas, saat ini sangat membutuhkan dukungan sistem informasi dalam peningkatan mutu pelayanan terhadap proses pendidikan. Proses pendidikan ini sangat banyak jenisnya diantaranya adalah bimbingan tugas akhir. Proses menulis skripsi atau tugas akhir adalah tahap akhir yang harus ditempuh oleh mahasiswa yang pada prosesnya dibimbing oleh dua orang dosen pembimbing. Dalam prakteknya aktifitas bimbingan tugas akhir ini dilakukan dengan diskusi, tanya jawab, pemberian masukan dan aktifitas lainnya. Kendala yang dihadapi dalam melakukan bimbingan dengan cara tatap muka yaitu sulitnya melakukan pencocokan waktu, form bimbingan yang tidak terorganisir sehingga dapat menyebabkan pencatatan yang tidak akurat serta mahasiswa diharuskan untuk selalu berada di kampus untuk mendapatkan informasi terbaru mengenai proses administrasi tugas akhir[1]. Untuk mengatasi permasalahan tersebut maka diperlukan perancangan apikasi daring bimbingan tugas akhir bagi mahasiswa dan dosen tanpa melalui tatap muka.
Penelitian terkait aplikasi bimbingan online mahasiswa pernah dilakukan oleh Muhammad Jaka P. Dalam aplikasi menggunakan lima tipe pengguna dan 10 pilihan menu. Tipe pengguna yang ada dalam aplikasi ini adalah Administrator, Dosen Pembimbing Skripsi, Ketua Program Studi, Staf Jurusan, dan Mahasiswa Jurdikmat UNY[2]. Penelitian mengenai bimbingan online lainnya dilakukan oleh Tjatur Kandaga dan Vinsensius Felix Aplikasi dalam penelitian ini memiliki tiga tipe pengguna dosen, mahasiswa dan ketua kelompok bidang keahlian. Aplikasi juga dapat menentukan secara otomatis pemilihan dosen pembimbing berdasarkan keahlian masing-masing[3]. Adapun penelitian lainnya dilakukan oleh Awaluddin Rizal dimana aplikasi yang dibuat dalam penelitian tersebut berbasis web dengan menggunakan teknologi JSP (Java Server Pages)[4].

Dari beberapa penelitian terkait sebelumnya, maka peneliti merancang sebuah aplikasi daring bimbingan tugas akhir yang didalamnya terdapat interaksi antara mahasiswa dan dosen begitu pula sebaliknya dan dibangun berbasis web dengan PHP. Ruang lingkup dalam penelitian ini adalahProgram Studi Teknik Informatika Universitas Tanjungpura. Aplikasi ini dibangun agar dapat mempermudah dan mempercepat proses bimbingan antara dosen dengan mahasiswa.

\section{KAJIAN PUSTAKA}

\section{A. Sistem Informasi}

Sistem informasi adalah sistem di dalam suatu organisasi yang mempertemukan kebutuhan pengolahan transaksi harian, membantu dan mendukung kegiatan operasi, bersifat manajerial dari suatu organisasi dan membantu mempermudah penyediaan laporan yang diperlukan[5].

\section{B. Alat Perancangan Sistem}

Dalam merancang suatu sistem terdapat banyak hal yang harus diperhatikan sehingga perlu digunakan alat bantu untuk memodelkan aplikasi yang akan dibuat. Terdapat banyak bentuk model yang dapat digunakan dalam perancangan sebuah sistem antara lain model narasi, prototype, model grafis atau diagram dan lain sebagainya. Pada dunia pemodelan sistem terdapat sejumlah cara merepresentasikan sistem melalui diagram misalnya data flow diagram (DFD). 
Data Flow Diagram (DFD) merupakan alat yang digunakan untuk menggambarkan suatu sistem yang telah ada atau sistem baru yang akan dikembangkan secara logika tanpa mempertimbangkan lingkungan fisik dimana data tersebut mengalir ataupun lingkungan fisik dimana data tersebut akan disimpan [6].

\section{Daring}

Menurut kamus besar bahasa Indonesia, daring dapat diartikan sebagai suatu keadaan yang sedang menggunakan jaringan, terhubung dalam jaringan, satu perangkat dengan perangkat lainnya yang terhubung sehingga bisa saling berkomunikasi.

\section{Bimbingan Tugas Akhir}

Menurut kamus besar bahasa Indonesia, bimbingan memiliki arti sebagai petunjuk (penjelasan) cara mengerjakan sesuatu, tuntunan atau pimpinan. Tugas akhir sendiri adalah karya ilmiah yang disusun oleh mahasiswa setiap program studi berdasarkan hasil penelitian suatu masalah yang dilakukan secara seksama dengan bimbingan dosen pembimbing[7].

\section{E. Basis Data}

Menurut Chou, basis data adalah kumpulan informasi yang bermanfaat yang diorganisasikann ke dalam tatacara yang khusus. Menurut Gabbri dan Schwab, basis data adalah sistem berkas terpadu yang dirancang terutama untuk meminimalkan pengulangan data. Sedangkan menurut Date, basis data dapat dianggap sebagai tempat untuk sekumpulan berkas dan terkomputerisasi yang tujuan utamanya adalah melakukan pemeliharaan terhadap informasi dan membuat informasi tersebut tersedia saat dibutuhkan. Secara konsep, basis data adalah kumpulan data yang membentuk suatu berkas atau file yang saling berhubungan dengan atacara yang tertentu untuk membentuk data baru atau informasi[8].

Sistem basis data merupakan perpaduan antara basis data dan sistem manajemen basis data. Basis data yang kompleks dan disertai dengan teknik pendokumentasian dan prosedur manipulasinya akan membentuk sistem manajemen basis data. Beberapa komponen-komponen sistem basis data adalah:

1. Perangkat keras (Hardware), sebagai pendukung operasi pengolahan data.

2. Sistem operasi.

3. Basis data.

4. Sistem pengelola basis data.

5. Aplikasi atau perangkat lunak lain yang bersifat opsional.

6. Pemakai/pengguna.

Pengguna basis data meliputi:

a. Database Administrator, yaitu pengguna yang memiliki kewenangan sebagai pusat pengendali seluruh sistem baik basis data maupun program- program yang mengaksesnya, menentukan pola struktur basis data, memodifikasi, membagi tugas pengolahan dan memberikan otoritas terentu.

b. Application Programmer, yaitu programmer aplikasi yang berinteraksi dengan sistem melalui pemanggilan Data Manipulation Language (DML) yang dimasukkan ke dalam program yang ditulis.

c. Sophisticated Users, yaitu pengguna yang berinteraksi dengan sistem tanpa harus menuliskan sendiri programnya, tetapi diganti dengan melakukan permintaan dalam bentuk bahasa query.

d. Specialized Users, yaitu pengguna yang menuliskan program aplikasi basis data khusus yang tidak sesuai dengan framework pemrosesan data tradisional.

e. Naive Users, yaitu kebanyakan pengguna yang berinteraksi dengan siste dengan cara memanggil salah satu program aplikasi yang telah disediakan.

\section{METODOLOGI PENELITIAN}

\section{A. Diagram Alir Penelitian}

Diagram alir penelitian merupakan sebuah diagram dengan simbol-simbol grafis yang menyatakan aliran algoritma atau proses yang menampilkan langkah-langkah penelitian yang disimbolkan dalam bentuk kotak, beserta urutannya dengan menghubungkan masing-masing langkah tersebut menggunakan tanda panah.

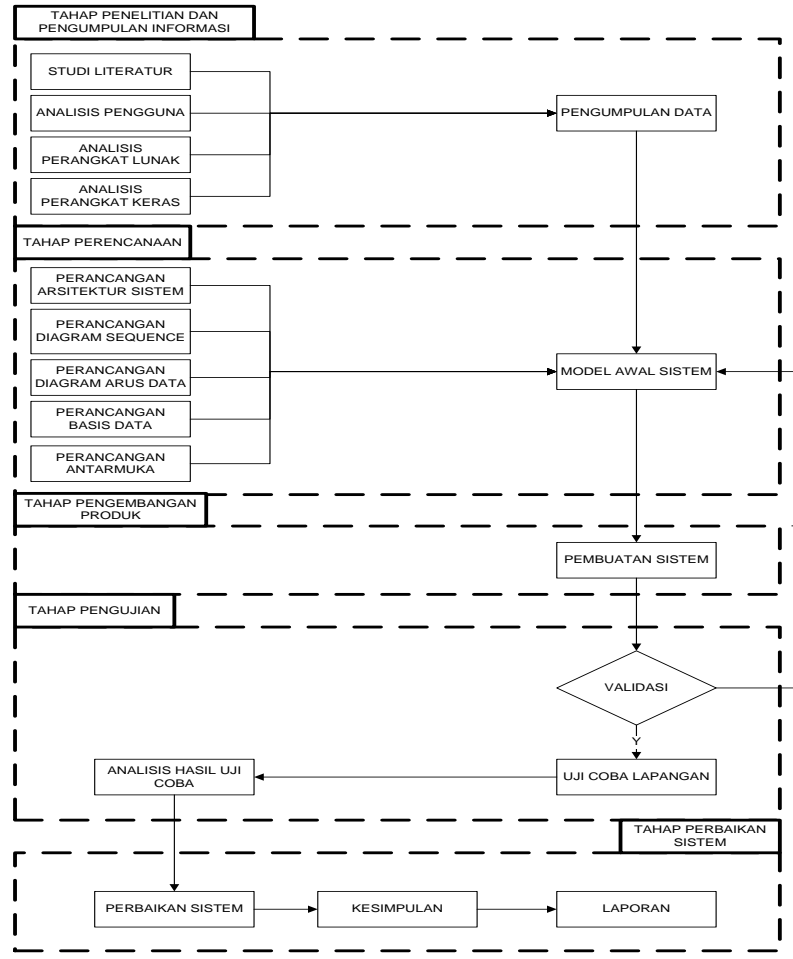

Gambar. 1 Diagram Alir Penelitian 
Gambar 5 merupakan diagram alir penelitian yang akan dilakukan. Langkah-langkah yang dilakukan dalam penelitian:

\section{Tahap Penelitian dan Pengumpulan Informasi}

a) Studi Literatur

Studi literatur dengan cara melakukan kajian teori melalui buku-buku dan sumber informasi lainnya yang berkaitan dengan sistem yang akan dibuat.

b) Analisis Pengguna

Analisis pengguna dilakukan untuk menjawab pertanyaan "siapa yang akan menggunakan sistem tersebut?".

c) Analisis Perangkat Lunak

Analisis perangkat lunak dilakukan untuk mengetahui perangkat lunak apa saja yang akan digunakan dalam pembuatan sistem dan disesuaikan dengan perangkat keras yang akan digunakan.

d) Analisis Perangkat Keras

Analisis terhadap perangkat keras dilakukan untuk mengetahui perangkat keras apa saja yang dapat mengakomodasi pembuatan sistem.

\section{Tahap Perencanaan}

Tahap ini merupakan tahap perancangan model awal sistem berdasarkan hasil pengumpulan informasi dari tahap pertama. Tahap perencanaan meliputi lima tahap, yaitu perancangan arsitektur sistem, perancangan diagram sequence sistem, perancangan diagram arus data, perancangan basis data serta perancangan antarmuka.

\section{Tahap Pembuatan Sistem}

Merupakan tahap pembuatan sistem sesuai dengan desain yang telah dibuat, meliputi pembuatan basis data, pembuatan antar muka serta pengkodean (coding). Hasil dari tahap ini merupakan produk awal dari sistem pendukung bimbingan online.

\section{Tahap Pengujian}

Pengujian dilakukan oleh pengguna untuk mengetahui kelayakan sistem yang telah dibuat serta tanggapan dan penilaian pengguna setelah menggunakan sistem. Kemudian dilakukan analisis dari hasil pengujian yang dilakukan.

\section{Tahap Perbaikan Sistem}

Perbaikan sistem dilakukan untuk memperbaiki kekurangan sistem yang didapat pada saat melakukan pengujian. Kemudian dilakukan penarikan kesimpulan dan penulisan laporan

\section{B. Diagram Konteks Sistem}

Diagram konteks adalah arus data yang berfungsi untuk menggambarkan keterkaitan aliran-aliran data antara sistem dengan bagian-bagian luar (kesatuan luar). Kesatuan luar ini merupakan sumber arus data atau tujuan data yang berhubungan dengan sistem informasi tersebut. Diagram konteks memberikan batasan yang jelas mengenai besaranbesaran entitas yang berada diluar sistem yang sedang dibuat, artinya diagram ini menggambarkan secara jelas batasanbatasan dari sebuah sistem yang sedang dibuat.

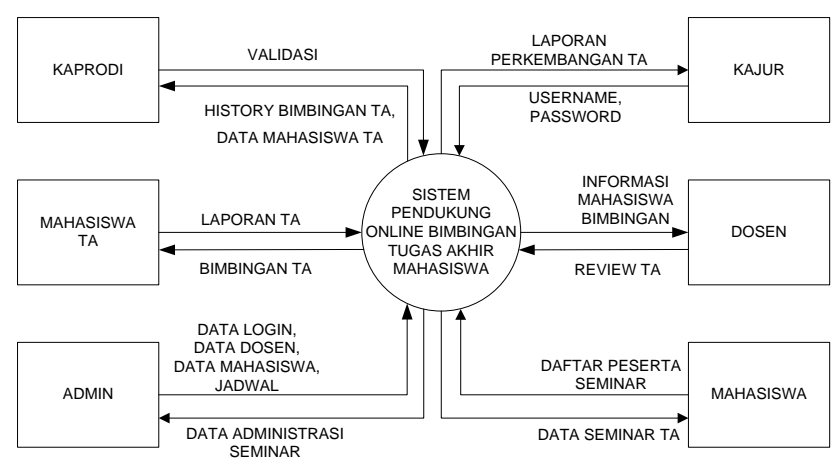

Gambar.2 Diagram Konteks Sistem

\section{HASIL DAN ANALISIS}

Aplikasi daring bimbingan tugas akhir ini merupakan aplikasi yang bertujuan mempermudah proses bimbingan tugas akhir antara dosen pembimbing dan mahasiswa bimbingannya, dapat menjadi forum komunikasi antara kedua dosen pembimbing dan dapat terpantau pelaksanaan bimbingan tugas akhir tersebut oleh Ketua Program Studi. Aplikasi ini dinamai dengan BIOTA. Berikut adalah tampilan dari Aplikasi:

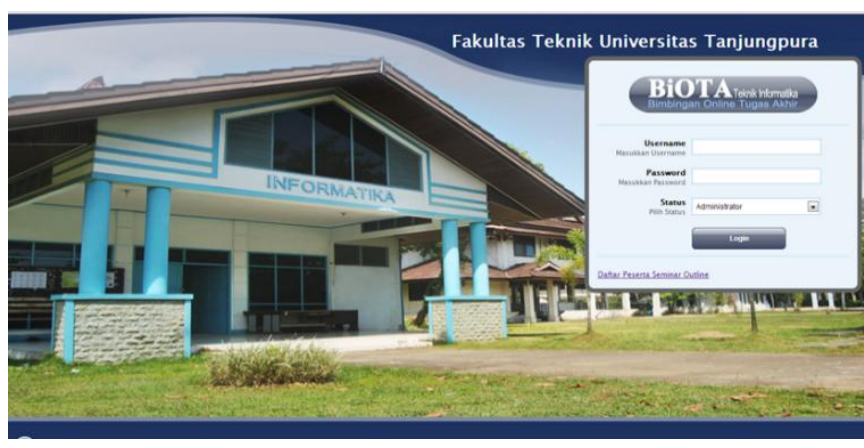

Gambar. 3 Antarmuka halaman login

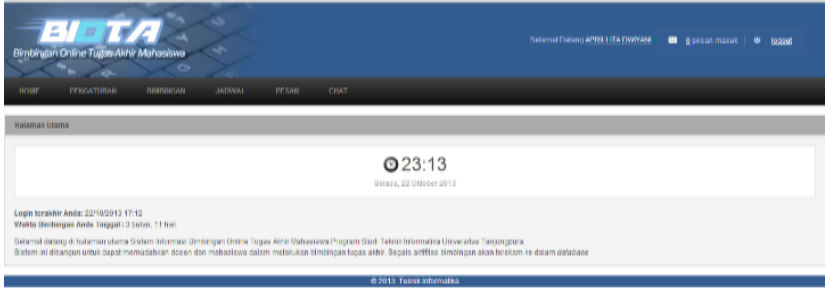

Gambar. 4 Antarmuka Halaman utama mahasiswa 


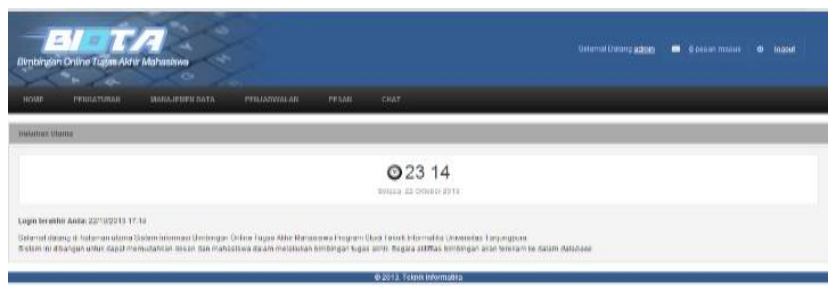

Gambar. 5 Antarmuka halaman utama admin, dosen, ketua program studi dan ketua jurusan

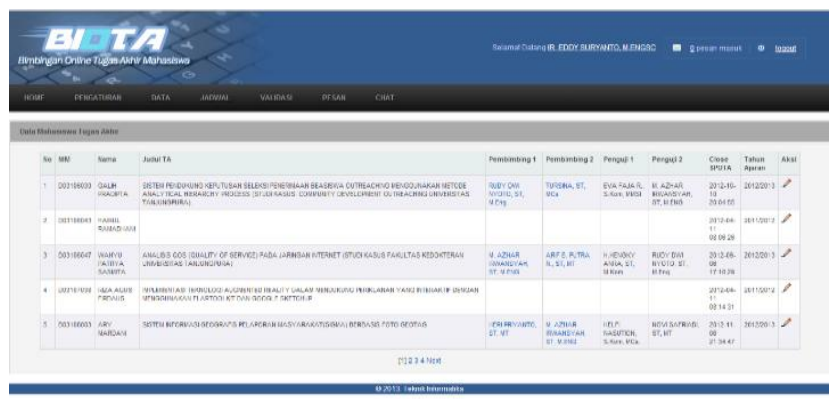

Gambar. 6 Antarmuka halaman data mahasiswa tugas akhir

Berikut ini adalah analisis hasil perancangan dan pengujian aplikasi daring bimbingan tugas akhir:

1. Mahasiswa hanya dapat login ke dalam sistem jika status SPOTA telah closed, yaitu judul pra-outline mahasiswa telah disetujui oleh minimal 4 (empat) orang dosen dan telah mendapatkan dosen pembimbing dan dosen penguji.

2. Hasil pengujian pengiriman email pemberitahuan menunjukkan bahwa jika mahasiswa mengirimkan diskusi bimbingan kepada dosen pembimbing, maka sistem akan secara otomatis mengirimkan email kepada dosen pembimbing, juga sebaliknya jika dosen pembimbing memberikan review bimbingan, maka sistem akan mengirimkan email kepada mahasiswa. Jika mahasiswa dinyatakan telah selesai bimbingan oleh kedua dosen pembimbing, maka sistem akan mengirimkan email pemberitahuan validasi kepada Ketua Program Studi untuk dinyatakan siap dilanjutkan dalam seminar outline maupun sidang skripsi. Dosen pembimbing dan dosen penguji akan mendapatkan email pemberitahuan jika waktu seminar atau sidang skripsi telah di jadwalkan.

3. Hasil perancangan dan pengujian sistem menunjukkan bahwa sistem ini menjadi solusi untuk proses bimbingan antara mahasiswa tugas akhir dan dosen pembimbing tanpa harus bertatap muka langsung, dapat menjadi forum komunikasi antara kedua pembimbing serta Ketua Program Studi dapat memantau bimbingan tugas akhir mahasiswa.

4. Berdasarkan hasil kuesioner, dapat disimpulkan bahwa perangkat lunak yang dirancang dinilai berhasil ditunjukkan dengan hasil perhitungan menggunakan skala Likert's Summated Rating (LSR)

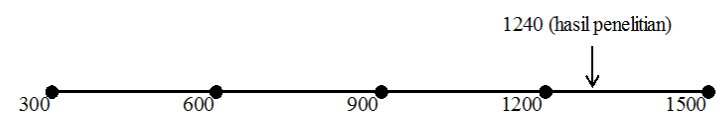

Gambar. 7 Hasil penelitian pada interpretasi LSR

\section{KESIMPULAN}

Berdasarkan hasil analisis dan pengujian terhadap Aplikasi Daring Bimbingan Tugas Akhir Mahasiswa Program Studi Teknik Informatika, maka dapat disimpulkan bahwa:

1. Aplikasi dapat membantu proses bimbingan tugas akhir antara dosen dan mahasiswa bimbingannya, karena proses bimbingan dapat dilakukan secara online serta dilengkapi dengan pemberitahuan secara realtime melalui pesan elektronik atau email.

2. Aplikasi memberikan kemudahan bagi kedua dosen pembimbing untuk berkomunikasi mengenai mahasiswa bimbingannya dalam forum pembimbing.

3. Aplikasi membantu Ketua Program Studi dan Ketua Jurusan dalam memantau perkembangan bimbingan tugas akhir mahasiswa.

\section{REFERENSI}

[1] Amalia K, Nuraini; Suryani, Arie Ardiyanti dan Saadah, Siti. 2012. Aplikasi Monitoring Bimbingan dan Pemantauan Prathesis Mahasiswa S2 Teknik Informatika Fakultas Pascasarjana IT Telkom. Bandung: Fakultas Informatika Institut Teknologi Telkom Bandung

[2] Jaka, Muhammad. 2014. Aplikasi Bimbingan Skripsi Online Mahasiswa Jurusan Pendidikan Matematika Fakultas Matematika Dan Ilmu Pengetahuan Alam Universitas Negeri Yogyakarta. Yogyakarta: Fakultas Matematika dan Ilmu Pengetahuan Alam Universitas Negeri Yogyakarta

[3] Kandaga, Tjatur dan Vinsensius Felix. 2011. "Pembuatan Aplikasi Pengelolaan Tugas Akhir Online Berbasis Web Studi Kasus Jurusan Teknik Informatika UKM". Jurnal Sistem Informasi, Vol. 6, No. 2, September 2011: 185 - 197

[4] Rizal, Awaluddin. 2011. Sistem Informasi Bimbingan Mahasiswa. Fakultas Teknologi Industri Universitas Pembangunan Nasional "Veteran" Jawa Timur

[5] Arbie, Erwan. 2000. Pengantar Sistem Informasi Manajemen. Edisi Ke-7, Jilid 1. Jakarta: Bina Alumni Indonesia

[6] Jogiyanto, HM. 2005. Analisis \& Desain Sistem Informasi: Pendekatan Struktur.Penerbit Andi Offset, Yogyakarta

[7] Hadary,Ferry, dkk. 2012. Pedoman Penulisan Skripsi. Fakultas Teknik Universitas Tanjungpura Pontianak

[8] Supriyanto, Aji. 2005. Pengantar Teknologi Informasi. Jakarta: Salemba Infotek 